\title{
INCIDENCE OF HEPATITIS B AND C VIRUSES AMONG THE SCAVENGERS IN KWARA STATE, NIGERIA
}

Yusuf Olanrewaju Raufu ${ }^{1}$, Adewoye Solomon Olayinka ${ }^{2}$, Sawyerr Henry Olawale ${ }^{1}$, Morufu Olalekan Raimi ${ }^{1 \& 3^{*}}$

${ }^{1}$ Department of Environmental Health Science, Kwara State University, Malete, Nigeria.

${ }^{2}$ Department of Pure and Applied Biology, Ladoke Akintola University of Technology, Ogbomosho.

${ }^{1 \& 3}$ Department of Community Medicine, Environmental Health Unit, Faculty of Clinical Sciences, Niger Delta University, Wilberforce Island, Bayelsa State, Nigeria.

E-mail: deentech06@gmail.com; soadewoye@lautech.edu.ng;

henry.sawyerr@kwasu.edu.ng, ola07038053786@gmail.com

\begin{abstract}
Background. Poor economic situations in developing nations had made scavenging a means of livelihood for millions of youth and women across the globe. Lack of proper source segregation of wastes in developing countries has increased the potential for the transmission of pathogens like
\end{abstract} Hepatitis B Virus $(H B V)$ and Hepatitis C Virus $(H C V)$.

Objectives. This study addressed issues relating to waste scavenging, the potential risk in waste scavenging work and seroprevalence of Hepatitis $B$ and $C$ Virus and its relationship with wastes scavenging among wastes scavengers in Kwara State.

Methods. A cross-sectional study was conducted among the scavengers working for major scrap dealers in the three senatorial districts of Kwara State. Consequently, to accomplish the objectives, both primary and secondary data sources were used. The primary data were collected via questionnaires, interviews, blood test and field observations. Whereas the secondary data were extracted from different published and unpublished materials. 240 respondents were administered with questionnaires and undergone hepatitis surface antigen test for both hepatitis $B$ and $C$ in nine of the sixteen local government area in the state. The data were analyzed using statistical package for social science (SPSS version 23) for descriptive and inferential at $5 \%$ level of significance. The prevalence of an $\mathrm{HBV}$ and $\mathrm{HCV}$ infection biological markers (HBsAg and HCsAg) and their associations with exposure to bio-medical waste, socio-demographic factors, and history of occupational injuries was examined.

Results. The seroprevalence of $H B V$ and $H C V$ infection among the scavengers were found to be $8.3 \%$ and $5 \%$ respectively indicating that scavengers are at risk of $H B V$ and $H C V$ infection.

Conclusions. It was discovered that there are incidences of Hepatitis $B$ and $C$ virus co-infection among scavengers. Also, awareness and compliance to the usage of PPE was found to be an important factor for protection scavengers against the virus. Therefore, vaccination against $H B V$, enforcement of usage of PPE, good hygiene practices, regular trainings on occupational safety, proper monitoring by regulatory agency and inclusion of scavengers in mandatory health insurance scheme will help to control risk of $H B V$ and HCV infection among scavengers.

Keywords: Hepatitis B Virus, Hepatitis C Virus, Scavengers, Seroprevalence, Personal Protective Equipment, Kwara South, Kwara North, Kwara Central, Health Insurance Scheme. 
medRxiv preprint doi: https://doi.org/10.1101/2022.01.26.22269849; this version posted January 28, 2022. The copyright holder for this preprint (which was not certified by peer review) is the author/funder, who has granted medRxiv a license to display the preprint in perpetuity.

It is made available under a CC-BY-NC-ND 4.0 International license .

\section{Introduction}

Wastes are inevitable remains from activities of human and animal. Daily activities of man entail constant discard of unwanted materials in form of wastes. Wastes management is therefore refers to the activities and actions required to manage waste from its inception to its final disposal [1]. While, municipal wastes are mixed and unsegregated at points of generation, undermining effective management when it comes to treatment and disposal practices. Indiscriminate disposal and sorting of mixed wastes by scavengers have the potential for increased environmental exposure to air pollution, toxic emissions from combusted or burnt municipal waste, proliferation of vermin and spread of diseases like hepatitis $[2,3,4,5,6,7,8,9,10]$. Hepatitis is an inflammatory condition of the liver and viral hepatitis is a conventional term used to denote hepatitis caused by hepatotrophic viruses Hepatitis A-G. High prevalence of these viruses especially hepatitis B is reported in Nigeria. Hepatitis B (alone accounting for nearly one million deaths annually) and $\mathrm{C}$ may cause liver cirrhosis and they can be contacted through contaminated blood and blood products [11].

Viral hepatitis has become a major health problem worldwide and cause acute and/or chronic hepatitis which can leads to the development of extensive liver scarring (cirrhosis), liver failure, liver cancer and death. As previous research has reported the endemic nature of viral hepatitis throughout sub-Saharan Africa and as a leading infectious killer globally, including its negative impact on human health $[12,13,14,15,16,17,18,19,20,21,22,23,24]$. While, viral hepatitis remains the tenth leading cause of death and the leading cause of liver cancer worldwide [25, 26]. It has also been suggested that hepatitis may increase the risk of pancreatic cancer [27]. Thus, the research is therefore, aimed at finding out the seroprevalence of hepatitis $\mathrm{B}$, hepatitis $\mathrm{C}$ and co-infection with Hepatitis B and C among scavengers in Kwara State, Nigeria. It is anticipated that the findings from this study will necessitate the need for thorough screening of blood among scavengers in Kwara State toward reducing risk among scavengers in Nigeria. The scope of the work is however narrowed to nine local government areas out of sixteen local government areas in the state. The respondents are therefore chosen in three local governments from each senatorial district of Kwara North, Kwara South and Kwara Central respectively. 


\section{Methodologies}

\section{Study Area}

Kwara state is located in the North Central Nigeria; it lies between $11^{\circ} 2$ and $11^{\circ} 45$ North and Longitude $2^{\circ} 45$ and 64 East (see figure 1 below) $[4,8,10]$. The state covers a land area of 35,705 square kilometers and has a population of 2,371,089 [27]. It has 16 Local Government Areas and the population of 2.37 million people according to 2006 census.

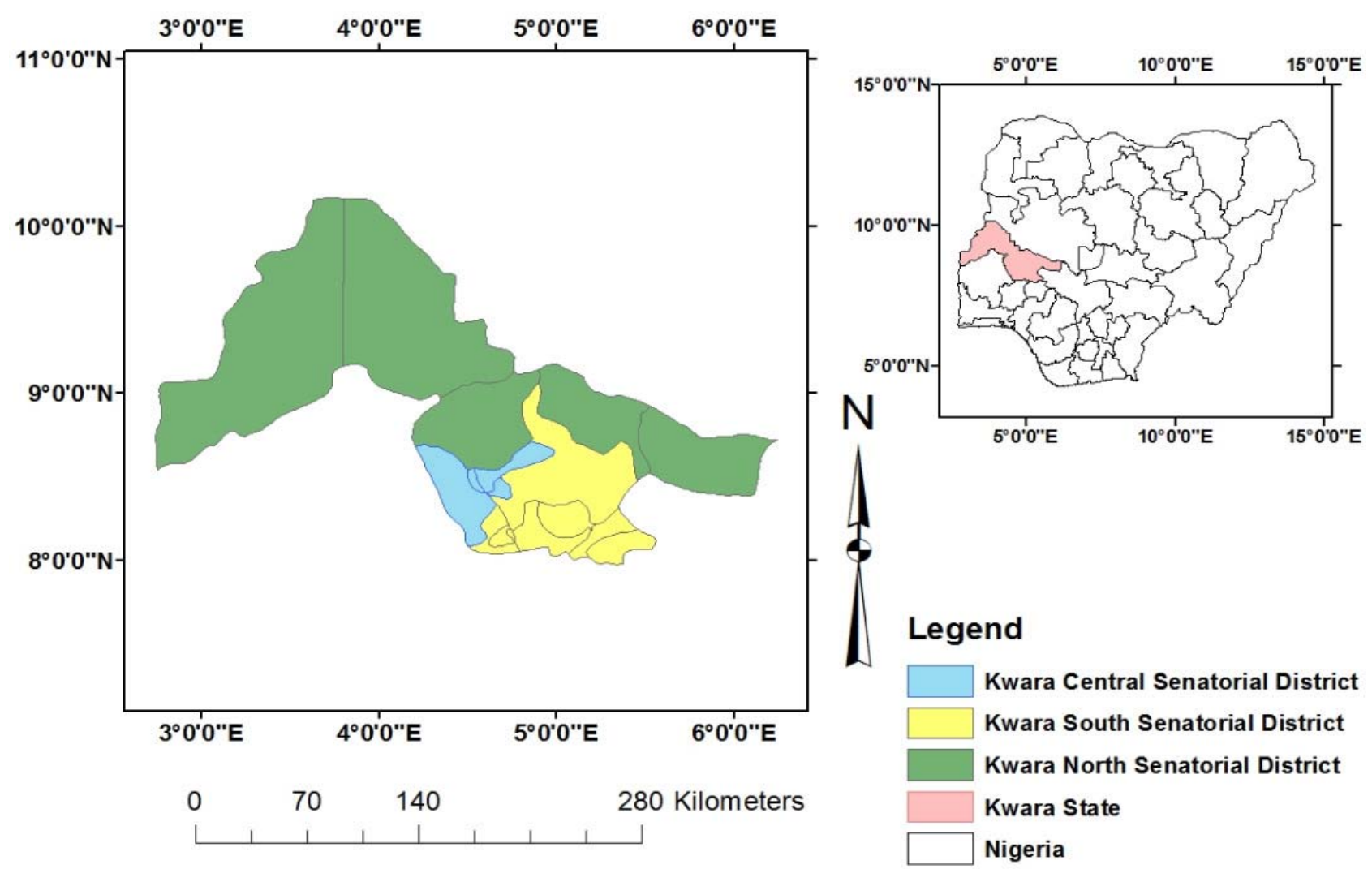

Figure 1: Map of Nigeria Showing Kwara State and the study areas

\section{Study Population}

The study population were scavengers working with major scrap dealers in Kwara State as well as on the dumpsites across the state.

\section{Sampling Techniques}

Scavengers were selected from the registered scrap dealers through the State Environmental Protection Agency (KWASEPA) as well as the association of scrap dealers working on the 
dumpsites. Respondents were administered with questionnaires and their consents were sought before proceeding to the second stage (Hepatitis B and C Screening) of the study. The appropriate sample size was determined using fishers sample size formula, the total sample size was determined as 240 including $10 \%$ non-response rate.

\section{Sample Collection}

Blood samples were collected with the help of a medical laboratory scientist from respondents at three dumpsites in Ilorin Metropolis using intravenous needles. The needles and syringes used for the collection of blood samples were dried and sterile. The serum obtained was tested for hepatitis B surface antigen (HBsAg) and anti-hepatitis $\mathrm{C}$ antibodies using a Diaspot rapid diagnostic test strip.

\section{Rapid Diagnostics Test}

The Diaspot rapid diagnostic test is used to qualitatively detect the presence of HBsAg and HCsAg in serum or plasma specimens. The test utilizes a combination of monoclonal and polyclonal antibodies to selectively detect elevated levels of HBsAg and HCsAg in serum or plasma. During testing, the serum or plasma specimen reacts with the particles coated with anti-HBsAg and anti-H anti-HCV antibody. The mixture migrates upward on the membrane chromatographically by capillary action to react with anti- HBsAg and anti-HVC antibodies on the membrane and generate a colored line. The presence of the colored line in the test region indicates a positive result, while its absence indicates a negative result. To serve as a procedural control, a colored line will always appear in the control line region indicating that the proper volume of specimen has been added and membrane wicking has occurred. The manufacturers' instructions were strictly followed in the performance of these tests. The test strips, serum or plasma specimens were allowed to equilibrate to room temperature $\left(15-30^{\circ} \mathrm{C}\right)$ prior to testing. The test device was placed on a clean, level surface and $60 \mu 1$ of serum or plasma was added to the sample well of the device. The sample rehydrated and was mixed with the red colloidal gold conjugate, which flowed into the membrane.

\section{Data Instrument}

A semi-structured, interviewer administered questionnaire was used to elicit information on the socio-demographics and occupational hazards of all respondents. The instrument was pre-tested using 24 scavengers at Amoyo town from a group similar to the main study group. Each question was translated into the local languages (i.e. Yoruba, Nupe, Fulani and Hausa) for those that could not 
read English, to help the respondents to give true and accurate answers.

\section{Data Analysis}

Data was analyzed using SPSS 23, using descriptive statistic such as mean, frequencies, charts and graphs. Also, inferential statistic using six different statistical tests were used for the analysis. The tests used are Pearson chi-square, likelihood ratio, linear-by-linear association, phi, Cramer's, and contingency coefficient using the level of significance (0.05).

\section{Ethical Approval}

Ethical clearance for this study was obtained from the Kwara State Ministry of Health Ethical Review Committee. Informed consent of participants were sought before taking part in the study.

\section{Results}

\section{Socio-Demographic Characteristics of scavengers}

Here we present the results of the wastes scavengers based on their age, marital status, educational level and tribal status respectively.

Table 1: Socio-demographic Characteristics of Respondents

\begin{tabular}{|l|l|l|}
\hline AGE & Frequency & Percent \\
\hline $10-20$ & 61 & 25.4 \\
\hline $21-30$ & 109 & 45.4 \\
\hline $31-40$ & 67 & 27.9 \\
\hline $41-$ above & 3 & 1.3 \\
\hline Total & 240 & 100.0 \\
\hline GENDER & Frequency & Percent \\
\hline Male & 231 & 96.2 \\
\hline Female & 9 & 3.8 \\
\hline Total & 240 & 100 \\
\hline TRIBE & Frequency & Percent \\
\hline Hausa & 194 & 80.8 \\
\hline Nupe & 8 & 3.3 \\
\hline Yoruba & 26 & 10.8 \\
\hline
\end{tabular}




\begin{tabular}{|l|l|l|}
\hline Igbo & 3 & 1.3 \\
\hline Fulani & 8 & 3.3 \\
\hline Others & 1 & 0.4 \\
\hline Total & 240 & 100.0 \\
\hline MARITAL STATUS & Frequency & Percent \\
\hline Single & 129 & 53.8 \\
\hline Married & 111 & 46.2 \\
\hline Total & 240 & 100 \\
\hline EDUCATIONAL QUALIFICATION & Frequency & Percent \\
\hline None & 68 & 28.3 \\
\hline Primary level & 93 & 38.8 \\
\hline Secondary level & 42 & 17.5 \\
\hline Tertiary level & 5 & 2.1 \\
\hline Islamiyah & 32 & 13.3 \\
\hline Total & 240 & 100.0 \\
\hline Sinre Aithon & & \\
\hline
\end{tabular}

\section{Source: Author field survey, 2021}

The Table 1 above shows results from wastes scavengers' socio-demographic data. While, figure 1 below indicate the incidence of hepatitis $\mathrm{B}$ virus among scavengers across the three senatorial districts in Kwara State. The results of hepatitis surface antigen test showed twenty-three (23) scavengers which equivalent $9.6 \%$ tested positive for hepatitis B across the three senatorial districts. The Kwara central senatorial district has the highest hepatitis B positive rate with ten (10) hepatitis B positive cases. Kwara south senatorial districts followed with seven (7) hepatitis B positive incidences and Kwara north senatorial districts has the least cases of hepatitis B positivity with six (6) cases. Figure 2 shows the Hepatitis $\mathrm{C}$ surface antigen screening for the scavengers and the results of the screening is as presented in the chart below. The overall percentage of hepatitis $\mathrm{C}$ positivity in the state was $5 \%$ and the results also show that Kwara central has the highest incidences of hepatitis $C$ with seven (7) cases of positivity. Kwara south hepatitis C positivity is next to Kwara central with three (3) cases and Kwara north maintained 
the least incidence of hepatitis C positive cases with just two (2) incidences. In the Figure 3, co-infection of scavengers with both hepatitis $\mathrm{B}$ and hepatitis $\mathrm{C}$ were examined and it was revealed that there are cases of scavengers being infected with both hepatitis B and hepatitis C. The chart below present the results of incidences of co-infection by scavengers. The results revealed there are seven (7) co-infection among the scavengers which constitutes $2.91 \%$ of the total scavenger population. It was revealed that Kwara central has the highest number of co-infection of hepatitis B and C with four (4) positive cases among the respondents while the two senatorial districts of Kwara south and Kwara north has two (2) cases of co-infection each. Figure 4 shows compliants of wastes scavengers to the use of personal protective equipment (PPE). Compliance to the use of PPE was determined by the frequency of the PPE usage. Those that make use of PPE for at least five days in a week are categorised to have complied with the use. Kwara south senatorial districts lead in terms of the usage of PPE with $48.5 \%$ compliants while Kwara central closely followed with $43.1 \%$ of their scavengers in the district. The least compliants was found in Kwara north with $33.8 \%$ of scavengers in Kwara north complied with PPE usage.

\section{HEPATITIS B}

120

100

80

60

40

20

10

0

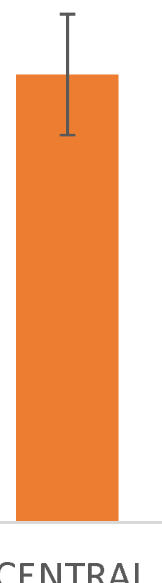

KWARA CENTRAL

KWARA SOUTH 
medRxiv preprint doi: https://doi.org/10.1101/2022.01.26.22269849; this version posted January 28, 2022. The copyright holder for this preprint (which was not certified by peer review) is the author/funder, who has granted medRxiv a license to display the preprint in perpetuity.

It is made available under a CC-BY-NC-ND 4.0 International license .

Figure 2 : Hepatitis B incidences among scavenger across the three senatorial districts.

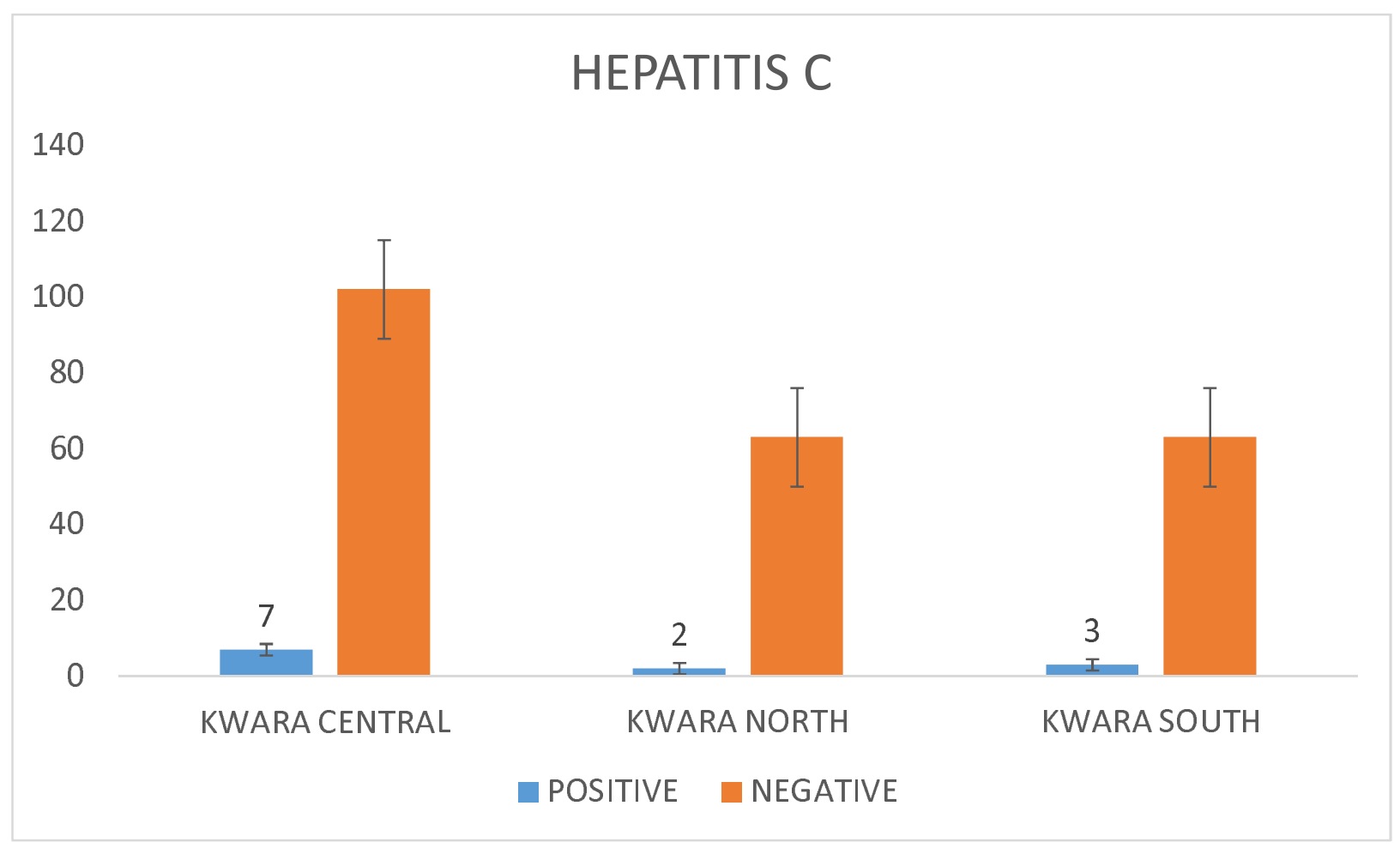

Figure 3 : Hepatitis $\mathrm{C}$ incidences among scavenger across the three senatorial districts.

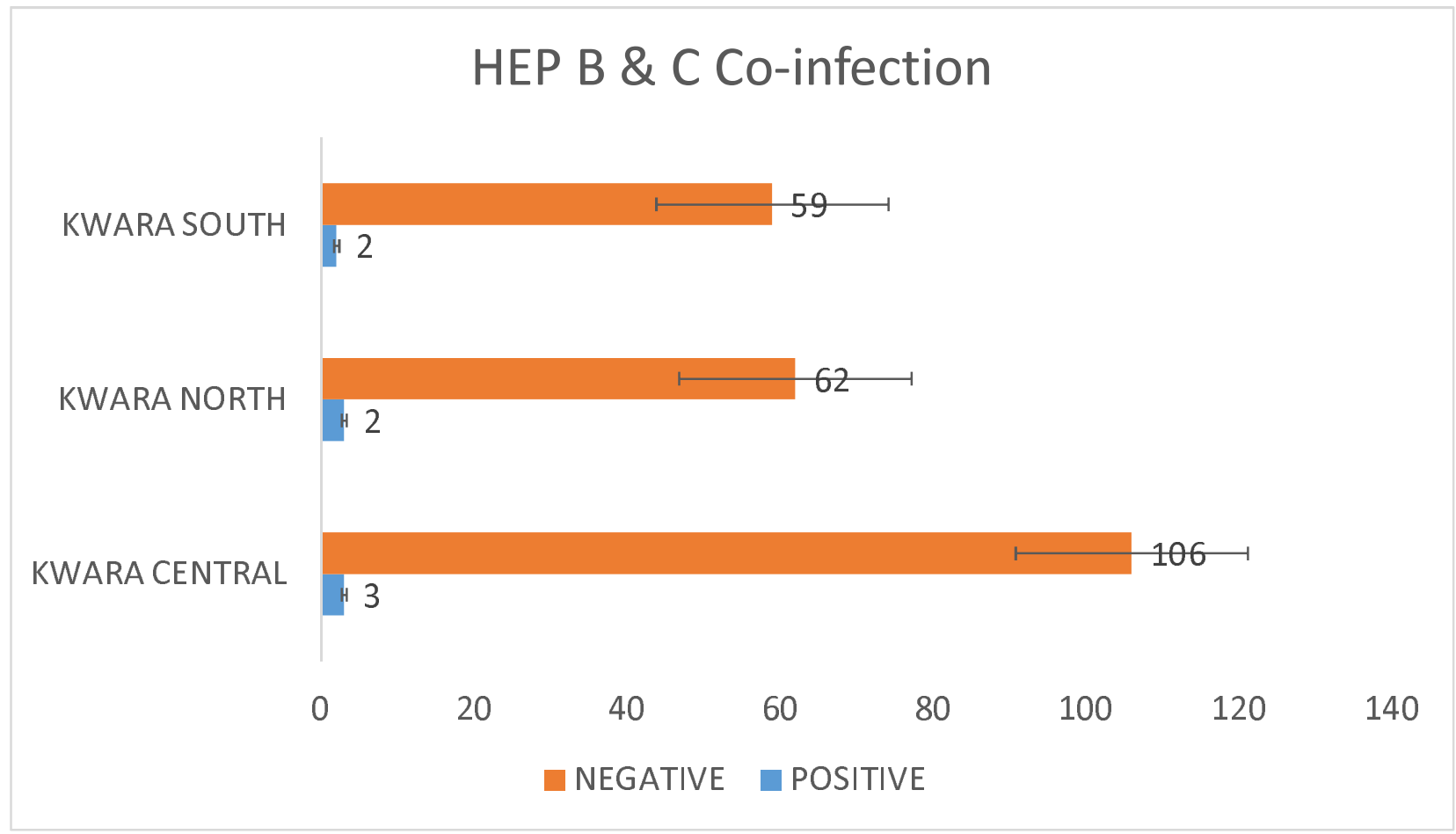


Figure 4: Co-infection of Hepatitis $B$ and $C$ incidences among scavenger across the three senatorial districts.

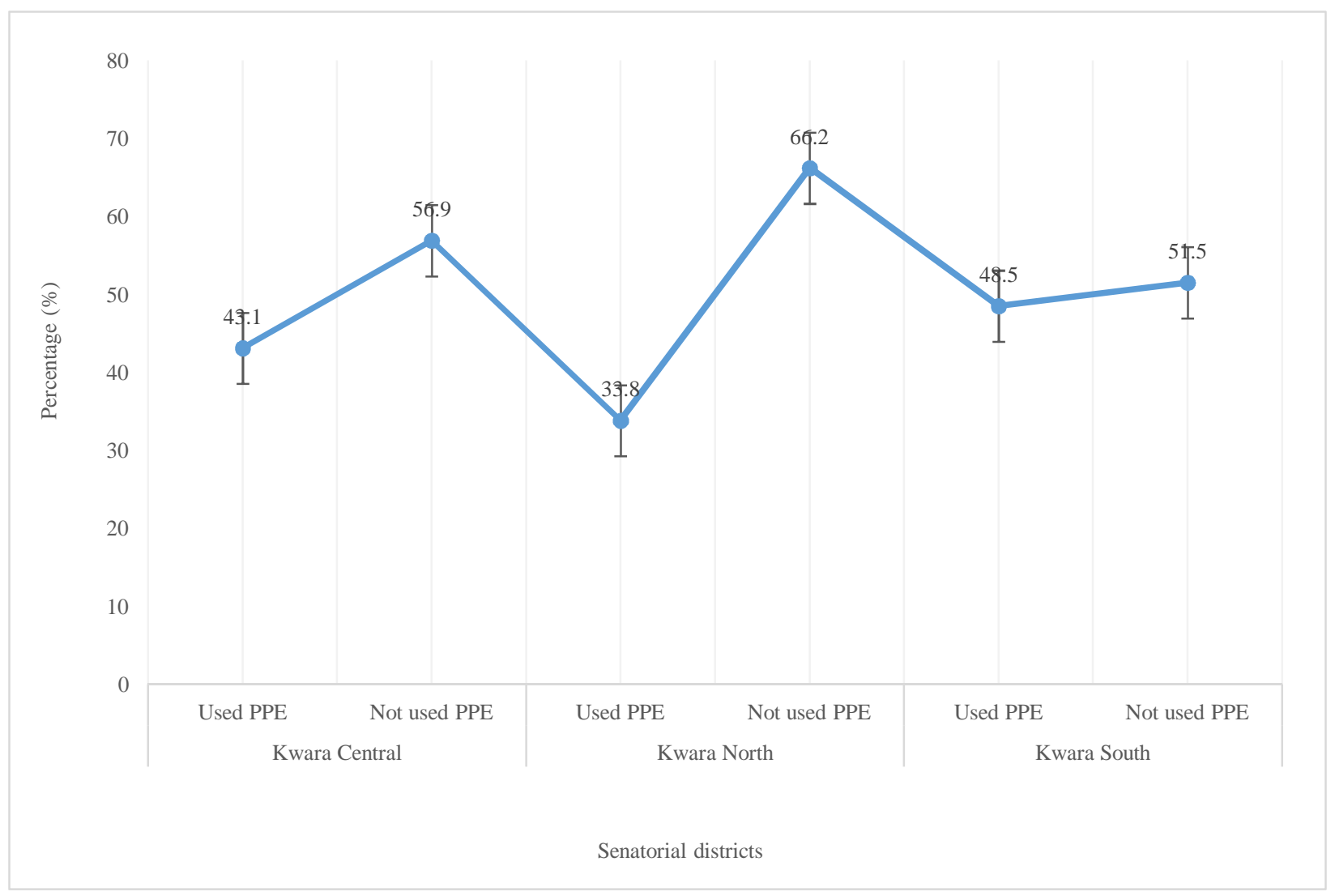

Figure 4 : Compliant to PPE usage across the three senatorial districts

\section{Discussion}

Nigeria is among the countries with a high burden of viral hepatitis with a Hepatitis B Virus (HBV) and Hepatitis C Virus (HCV) prevalence of $11 \%$ and $2.2 \%$, respectively [28]. This study revealed that majority of the scavengers in the study are in the age bracket $21-30$ years which is $45.4 \%$ that is in agreement with Irabor et al [29] which concluded that the highest population of scavengers i.e., 36\% are in the age bracket 20 - 29 years and Isaac et al [30] stated that majority $35.42 \%$ of respondents are between 18-28 years. In terms of education, majority of wastes scavengers in Kwara state all to the category of primary school leavers as the constitute $38.8 \%$ of total respondents and closely followed by those without any formal education which constitute $28.3 \%$. Secondary school certificate holders constitute $17.5 \%$ while only $2.1 \%$ of scavengers has 
a higher educational certificate. This is in agreement with Adebola et al [31] in his work on wastes worker and scavengers where he found that majority (51.1\%) of scavengers in Ibadan are primary school leavers. Scavenging job was found to be a male dominated occupation because $93.6 \%$ of respondents in this study are male scavengers which agrees with the work of Oteng-Ababio [32] which stated that about $90 \%$ of the scavenger population are male while female scavengers constitute approximately $10 \%$ in Kumasi. Similarly, in another study male made up $86 \%$ of e-waste scavengers found at the Agbogbloshie e-waste scrap yard in Accra as reported by Rankokwane and Gwebu, [33] and Afon [34]. It was also discovered that majority of scavengers are immigrant from the northern part of the country and this is because $80.8 \%$ of respondents of this study are Hausa by tribe and this agrees with Pinto [35] that asserted that majority of scavengers are immigrants. In terms of marital status, it was found that $53.8 \%$ of the scavengers are still unmarried and this three (3) can be as a result of high population of young adults that constitute majority of respondents. The research findings show incidence of hepatitis B and hepatitis $\mathrm{C}$ and co-infection with hepatitis $\mathrm{B}$ and $\mathrm{C}$ among wastes scavengers in Kwara state. Seroprevalence of hepatitis B detected through the use of hepatitis B test strip. Micro point brand was used for rapid test of the blood samples of scavengers. The results of hepatitis surface antigen test showed twenty-three (23) scavengers which equivalent $9.6 \%$ tested positive for hepatitis B. Across the three senatorial districts, Kwara central has the highest hepatitis B positive rate with ten (10) hepatitis B positive cases. Kwara south followed with seven (7) hepatitis B positive incidences and Kwara north has the least cases of hepatitis B positivity with six (6) cases. This is in agreement with the work of Yusuf et al [36] which also shows a high hepatitis B positivity among scavengers in Ilorin metropolis. Also, the result corroborates Sawyerr et al [2] in their findings that revealed higher incidence of hepatitis B virus among wastes scavengers in comparison with the municipal street sweepers. Hepatitis C screening for the scavengers and the results show the overall percentage of hepatitis $\mathrm{C}$ positivity in the state to be $5 \%$ and the results also indicated that Kwara central has the highest incidences of hepatitis $\mathrm{C}$ with seven (7) cases of positivity. This can be as a result of higher population of the state capital and proliferation of illegal dumpsites. Kwara south hepatitis C positivity is next to Kwara central with three (3) cases and Kwara north maintained the least incidence of hepatitis $\mathrm{C}$ positive cases with just two (2) 
incidences. This incidence of hepatitis $\mathrm{C}$ virus is higher than the national average occurrences in non-wastes workers as reported to be 2.2\%, [28]. Also, in another work by Agbede et al. [37] which stated that the $\mathrm{HCV}$ prevalence of $1.4 \%$ was seen among mothers in Ilorin metropolis. Though this research supported the findings of Adewuyi [38] who reported 5\% prevalence of antibodies to hepatitis $\mathrm{C}$ virus among normal blood donors and multi-transfused sickle-cell anaemia patients in the same environment. The distribution of co-infection of scavengers with both hepatitis B and hepatitis C across the state was 7 (2.92\% ) co-infection. This result is very close to the findings of Taiwo et al. [39] in their study on patients in Lagos State University Teaching Hospital (LASUTH), where it was reported that Dual presence of HBsAg and anti-HCV was observed in 4(3.9\%). It was revealed that Kwara central came top with 3 (42.8\% of positive) co-infection cases while Kwara south and Kwara north has 2 (28.6\% of positive) co-infection cases.

\section{Conclusion}

This study revealed that the seroprevalence of hepatitis B among scavengers in the state which $9.6 \%$ is still under the national average but hepatitis $\mathrm{C}$ was found to be $5 \%$ which is greater than the national average. It is therefore recommended that enabling law should be promulgated to regulate scavenging and make mandatory data capture of all scavengers. This will help the Government to know the population of scavengers and make adequate provision for their enlightenment and intervention that reduce the health burden of scavengers. Government agencies like the Kwara Environmental Protection Agency (KWASEPA) and the Ministry of Environment and Forestry should ensure that scavengers are adequately making use of PPE with strict enforcement measures. Free vaccination against HBV should be provided for scavenger, educational campaigns and regular training on occupational health and safety programs and health surveillance should be instituted for all waste scavengers with emphasizes on good work practices and personal hygiene practices.

\section{Study Limitations}

The small number of samples used in this study could place a limit to the outcome of this study. This is largely attributed to limited funds as there is no grant and sponsorship from any agencies.

\section{Acknowledgements}


The authors remain sincerely grateful to all scavengers that participated in the study and also all medical laboratory scientists and research assistant who provided logistic support during this study.

\section{Data availability}

The data used to support the findings of this study are included in the article. The raw data of this study will be made available on request. All requests should be made to the corresponding author of this article.

\section{Scavenger consent. Obtained}

Ethics approval. Ethical approval was granted from the Kwara State Ministry of Health Ethical Review Committee. Informed consent was obtained from each respondent.

Competing Interests. The authors declare no competing interests.

\section{References}

1. Amuda OS (2014) 'Challenges and Possible Panacea to the Municipal Solid Wastes Management in Nigeria' (2014) Journal of Sustainable Development Studies 67.

2. Sawyerr O. Henry, Rauf O. Yusuf, Adedotun T. Adeolu (2016). Risk Factors and Rates of Hepatitis B Virus Infection among Municipal Waste Management Workers and Scavengers in Ilorin, Kwara State, Nigeria. Journal of Health \& Pollution. Vol. 6, No. 12 — December 2016.

3. Raimi, MO, Pigha, TK and Ochayi, EO (2017) Water-Related Problems and Health Conditions in the Oil Producing Communities in Central Senatorial District of Bayelsa State. Imperial Journal of Interdisciplinary Research (IJIR) Vol-3, Issue-6, ISSN: 2454-1362.

4. Raimi MO, Adeolu AT, Enabulele CE, Awogbami SO (2018a) Assessment of Air Quality Indices and its Health Impacts in Ilorin Metropolis, Kwara State, Nigeria. Science Park Journals of Scientific Research and Impact Vol. 4(4), pp. 060-074, September 2018 ISSN 2315-5396, DOI: 10.14412/SRI2018.074.http://www.scienceparkjournals.org/sri/pdf/2018/September/Olale kan_et_al.pdf.http://www.scienceparkjournals.org/sri/Content/2018/September/2018.htm. 
5. Raimi MO, Tonye VO, Omidiji AO, Oluwaseun EO (2018) Environmental Health and Climate Change in Nigeria. World Congress on Global Warming. Valencia, Spain. December 06-07, 2018.

6. Adeolu T., Odipe OE and Raimi MO (2018). Practices and Knowledge of Household Residents to Lead Exposure in Indoor Environment in Ibadan, Oyo State, Nigeria. Journal of Scientific Research \& Reports 19(6): 1-10, 2018; Article NO. JSRR.43133 ISSN: 2320-0227.

7. Suleiman RM, Raimi MO and Sawyerr HO (2019) A Deep Dive into the Review of National Environmental Standards and Regulations Enforcement Agency (NESREA) Act. International Research Journal of Applied Sciences. pISSN: 2663-5577, eISSN: 2663-5585. DOI No. Irjas.2019.123.123. N ww.scirange.com. https://scirange.com/abstract/irjas.2019.108.125.

8. Raimi MO, Adio ZO, Odipe OE, Timothy KS, Ajayi BS \& Ogunleye TJ (2020) Impact of Sawmill Industry on Ambient Air Quality: A Case Study of Ilorin Metropolis, Kwara State, Nigeria. Energy and Earth Science Vol. 3, No. 1, 2020. URL: http://dx.doi.org/10.22158/ees.v3n1p1. www.scholink.org/ojs/index.php/ees ISSN 2578-1359 (Print) ISSN 2578-1367 (Online)

9. Morufu OR, Tonye VO \& Adedoyin OO (2021)Creating the Healthiest Nation: Climate Change and Environmental Health Impacts in Nigeria: A Narrative Review. Scholink Sustainability in Environment. ISSN 2470-637X (Print) ISSN 2470-6388 (Online) Vol. 6, No. $\quad 1, \quad 2021 \quad$ www.scholink.org/ojs/index.php/se. $\quad$ URL: http://dx.doi.org/10.22158/se.v6n1p61. http://www.scholink.org/ojs/index.php/se/article/view/3684.

10. Raimi, OM., Samson, TK., Sunday, AB., Olalekan, AZ., Emmanuel, OO., \& Jide, OT. (2021). Air of Uncertainty from Pollution Profiteers: Status of Ambient Air Quality of Sawmill Industry in Ilorin Metropolis, Kwara State, Nigeria. Research Journal of Ecology and Environmental Sciences, 1(1), 17-38. DOI: 10.31586/rjees.2021.010102. Retrieved from https://www.scipublications.com/journal/index.php/rjees/article/view/60. 
11. Adeyemi, AS., Olorunfemi, JF., \& Adewoye, TO (2001). Waste scavenging in Third World cities: A case study in Ilorin, Nigeria. Environmentalist, 21(2), 93-96. https://doi.org/10.1023/A:1010655623324.

12. Raimi MO, and Ochayi EO. (2017) Assessment of the Rate of Sexually Transmitted Diseases in Kubwa F.C.T. Abuja, Nigeria, Science Journal of Public Health. Vol. 5, No. 5, 2017, Pp. 365-376. DOI: 10.11648/J.Sjph.20170505.12.

13. Raimi MO, Omidiji AO, Ebikapaye O, Moses T, Adeolu TA, Makanjuola BC (2019), Situational Analysis of National Immunization Programme in Nigeria, Journal of Immunology and Inflammation Diseases Therapy. Doi: http://dx.doi.org/10.31579/2637-8876.2019/008.

14. Omidiji AO and Raimi MO (2019) Practitioners Perspective of Environmental, Social and Health Impact Assessment (ESHIA) Practice in Nigeria: A Vital Instrument for Sustainable Development. Paper Presented at the Association for Environmental Impact Assessment of Nigeria (AEIAN) On Impact Assessment: A Tool for Achieving the Sustainable Development Goals in Nigeria, 7th and 8th November, 2019 In University of Port

Harcourt. https://aeian.org/wp-content/uploads/2019/08/EIA-Presentations-Portharcourt.pdf.

15. Raimi MO, Omidiji AO, Adio ZO (2019) Health Impact Assessment: A Tool to Advance the Knowledge of Policy Makers Understand Sustainable Development Goals. Conference paper presented at the: Association for Environmental Impact Assessment of Nigeria (AEIAN) On Impact Assessment: A Tool for Achieving the Sustainable Development Goals in Nigeria, 7th and 8th November, 2019 in University of Port Harcourt.

DOI: $\underline{10.13140 / R G .2 .2 .35999 .51366}$ https://www.researchgate.net/publication/337146101.

16. Olalekan RM, Oluwatoyin OA, Olawale SH, Emmanuel OO, Olalekan AZ (2020) A Critical Review of Health Impact Assessment: Towards Strengthening the Knowledge of Decision Makers Understand Sustainable Development Goals in the Twenty-First Century: Necessity Today; Essentiality Tomorrow. Research and Advances: 
medRxiv preprint doi: https://doi.org/10.1101/2022.01.26.22269849; this version posted January 28, 2022. The copyright holder for this preprint (which was not certified by peer review) is the author/funder, who has granted medRxiv a license to display the preprint in perpetuity.

It is made available under a CC-BY-NC-ND 4.0 International license .

Environmental Sciences. 2020(1): 72-84. DOI: 10.33513/RAES/2001-13. https://ospopac.com/journal/environmental-sciences/early-online.

17. Olalekan RM, Oluwatoyin O and Olalekan A (2020) Health Impact Assessment: A tool to Advance the Knowledge of Policy Makers Understand Sustainable Development Goals: A Review. ES Journal of Public Health; 1(1); 1002. https://escientificlibrary.com/public-health/in-press.php.

18. Adedoyin OO, Olalekan RM, Olawale SH, et al (2020). A review of environmental, social and health impact assessment (Eshia) practice in Nigeria: a panacea for sustainable development and decision making. MOJ Public Health. 2020;9(3):81 $\square 87$. DOI: 10.15406/mojph.2020.09.00328.

https://medcraveonline.com/MOJPH/MOJPH-09-00328.pdf.

19. Raimi MO, Ihuoma BA, Esther OU, Abdulraheem AF, Opufou T, Deinkuro NS, Adebayo PA and Adeniji AO (2020) "Health Impact Assessment: Expanding Public Policy Tools for Promoting Sustainable Development Goals (SDGs) in Nigeria”. EC Emergency Medicine and Critical Care 4.9 (2020).

20. Raimi MO, Moses T, Okoyen E, Sawyerr HO, Joseph BO, Oyinlola BO (2020) “A Beacon for Dark Times: Rethinking Scientific Evidence for Environmental and Public Health Action in the Coronavirus Diseases 2019 Era" Medical and Research Microbiology, Vol. 1, Issues 3.

21. Raimi MO \& Raimi AG (2020). The Toughest Triage in Decision Impacts: Rethinking Scientific Evidence for Environmental and Human Health Action in the Times of Concomitant Global Crises. CPQ Medicine, 11(1), 01-05.

22. Raimi, MO., Mcfubara, KG., Abisoye, OS., Ifeanyichukwu EC., Henry SO., \& Raimi, GA (2021) Responding to the call through Translating Science into Impact: Building an Evidence-Based Approaches to Effectively Curb Public Health Emergencies [COVID-19 Crisis]. Global Journal of Epidemiology and Infectious Disease, 1(1). DOI: 10.31586/gjeid.2021.010102. Retrieved from https://www.scipublications.com/journal/index.php/gjeid/article/view/72. 
23. Raimi OM, Lucky EC, Okoyen E, Clement A, Ogbointuwei C, et al. (2021) Making Better Informed, More Confident COVID-19 Decisions: Vaccine Hesitancy, Its Barriers and Impact Studies: Taking Bayelsa State as an Example. Int $J$ Vaccine Immunizat 5(1): dx.doi. org/10.16966/2470-9948.126.

24. Morufu OR, Aziba-anyam GR and Teddy CA (2021) 'Silent Pandemic': Evidence-Based Environmental and Public Health Practices to Respond to the Covid-19 Crisis.

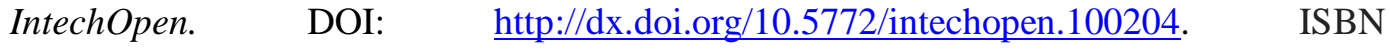
978-1-83969-144-7.

https://www.intechopen.com/online-first/silent-pandemic-evidence-based-environmentaland-public-health-practices-to-respond-to-the-covid-19-Published: December 1st 2021; ISBN: 978-1-83969-144-7; Print ISBN: 978-1-83969-143-0; eBook (PDF) ISBN: 978-1-83969-145-4. Copyright year: 2021.

25. Mahoney FJ, Kane M (1999): Hepatitis B vaccine 3 edition. Edited by: Plotkin SA, Orenstein WA. Philadelphia: W.B. Saunders company; 1999:158-182.

26. Feitelson MA, Sun B, Satiroglu Tufan NL, Liu J, Pan J, Lian Z (2002): Genetic mechanisms of hepatocarcinogenesis. Oncogene 2002, 21:2593-2604.

27. Becans (2007), "Business Environment Report,” African Institute for Applied Economics, Enugu, Vol. 1, No. 25, p. 8.

28. Federal Ministry of Health. National AIDS/STIS control program. 2016. https:// www. hepb. org/ assets/ Uploads/ Niger ia- Hepatitis- Guide lines-TX- guide lines. pdf. Accessed 29 Sept 2021

29. Irabor, G. I., Omotoso, A. J., Isiwele, E. M., Nnoli, M., \& Omoruyi, K. A. (2017). Histopathological study of cervical cancer specimen at the university of Calabar teaching hospital, Calabar. Medico Research Chronicles, 4(06), 582-590.

30. Isaac, I., Habila, J., Salami, H., \& Olivia, ON. (2020). Health Impacts of Informal Solid Waste Scavenging in Minna, Nigeria. Health, 6(12), 53-57.

31. Adebola, OO (2006) 'The Roles of Informal Private Sector in Integrated Solid Waste Manage- ment in the Achievement of Millennium Development Goals (MDG's) in Lagos 
Nigeria' (Solid Waste, Health \& Millennium Development Goals, CWG-WASH Workshop, Kolkata, 2006)

32. Oteng-Ababio, M. (2012). When Necessity Begets Ingenuity: E-Waste Scavenging as a Livelihood Strategy in Accra, Ghana. African Studies Quarterly, 13.

33. Rankokwane, B., \& Gwebu, TD. (2006). Characteristics, threats and opportunities of landfill scavenging: The case of Gaborone-Botswana. GeoJournal, 65(3), 151-163.

34. Afon A., (2012) “A survey of operational characteristics, socioeconomic and health e $\square$ ects of scavenging activity in Lagos, Nigeria," Waste Management and Research, vol. 30, no. 7, pp. 664-671, 2012. [3].

35. Pinto, V.N. (2008). "E-waste Hazard: Impending Challenge." Indian Journal of Occupational and Environmental Medicine 12: 65-70.

36. Yusuf RO., Henry OS, Adedotun TA, Lateefat MH, and Tawakalitu TA (2018). Seroprevalence of Hepatitis B Virus and Compliance to Standard Safety Precautions among Scavengers in Ilorin Metropolis, Kwara State, Nigeria. J. Health Pollu 2018 Sep; 8(19): 180914. Published online 2018 Sep 10. doi: 10.5696/2156-9614-8.19.180914.

37. Agbede, OO., Iseniyi, JO., Kolawole, OM, Ojuawo, A. (2006): Risk Factors and Seroprevalence of Hepatitis C antibody in mothers and their Pre-school age children in Ilorin. African Journal of Clinical and Experimental Microbiology Vol 7 No 3 AJCEM/2006112/2627 Copyright 2006 AFR.J/CI.N. EXPER MICROBIOL,7(3): 153-157.

38. Adewuyi. JO (1996). Prevalence of antibodies to hepatitis C Virus among patients in Nigeria. Tropical Doctor 1596:26:29-30.

39. Taiwo MB, Samuel E, Emmanuel FO (2012) HIV, Hepatitis B and C viruses' coinfection among patients in a Nigerian tertiary hospital. Pan Afr Med J. 12: 100. 